\title{
O LUGAR COMUM DA POESIA DE ANTÓNIO FRANCO ALEXANDRE: UM CORPO DE SENTIDOS E OUTRAS FANTASIAS POLÍTICAS
}

RESUMO: A partir de uma leitura da obra do poeta português António Franco Alexandre, procuramos depreender de seus usos de linguagem alguns procedimentos que permitam o reconhecimento de sua poética como um corpo de sentidos. A expressão busca situar o gesto criativo num espaço tenso entre a experiência carnal como acesso ao sagrado e a inexorável precariedade dos corpos. Enfim, a marca destes dois movimentos como figuração do intercâmbio obra/leitor é indício dos efeitos de indecidibilidade, tão próprios desta obra.

PALAVRAS-CHAVE: António Franco Alexandre; poesia portuguesa contemporânea; corpo de sentidos; erotismo.
ABSTRACT: By means of a reading of António Franco Alexandre's work, we note in his poetic language some procedures that allow recognizing it as a body senses. This expression includes the creative gesture in a tense space between the carnal experience as an access to sacred and the inexorable body precariousness. Anyway, this two movements as a figuration of the relationship between the work and its reader is a mark of the undecidability effects, label of this writing.

KEYWORDS: António Franco Alexandre; Contemporary Portuguese poetry; body senses; eroticism. 
Em entrevista concedida à Ana Marques Gastão e publicada no livro $O$ falar dos poetas, o poeta português António Franco Alexandre trata de questões recorrentes ao longo de sua produção, mas, principalmente, remonta a tópicos presentes em seus Quatro caprichos. Este texto, muito especificamente, é um marco de transição da trajetória do poeta. Após a publicação, em 1996, de sua antologia poética denominada simplesmente Poemas, sua obra passa por uma viragem fundamental, cisão estilística que salta aos olhos de qualquer leitor menos informado. Sua poética que, anteriormente, apostava em efeitos de linguagem proporcionados por quebras sintáticas, um complexo de referências que se justapunha ao próprio texto e construções imagéticas radicalmente inusitadas, agora é reformulada numa concepção estética a qual equilibra o rigor do verso a uma maior discursividade, enquanto que a sua irreversível preocupação com a linguagem no poema passa a apresentar-se como encenação a que explicitamente é problematizada no âmbito temático.

Enfim, num momento de maturidade, a escrita de Franco Alexandre torna-se mais limpa e precisa quanto aos seus projetos, de maneira que, ainda mais acentuadamente, cada obra sua ganhe a forma de um universo muito particular. Deste modo, o que lemos, por exemplo, em Quatro caprichos é intransferível a qualquer outro texto, assim como em Uma fábula ou Duende. Acreditamos que o veemente caráter narrativo destes livros reforce a unidade lida neles, posto que nos são apresentados personagens e pequenos enredos que acabam por determinar uma maior singularidade do texto.

Quanto a estes mesmos Quatro caprichos, estamos diante de uma obra partida em quatro poemas com variações de teor narrativo que podem ser assimiladas em dois blocos: ímpares ( 1 e 3 ) e pares ( 2 e 4). O obstáculo que se enfrenta ao analisar este texto é a diversidade intrínseca a esta obra, embora os poemas, por mais que sejam distintos entre si, formem um conjunto interdependente. Poderíamos discutir alguns pontos comuns que costuram cada um destes poemas de forma a assinalar um fio condutor da leitura, observadas as suas devidas especificidades. Assim, o próprio poeta nos oferece uma perspectiva de estudo quando, perguntado sobre o caráter de improviso musical destes versos, responde ser, não tão somente a música a guiar os percursos destes caprichos, mas a fantasia:

O livro tem uma construção musical, sim, daí os quatro andamentos: alegro,andante, scherzo e finale. Os caprichos têm um lado de improvisação, de exercício de estilo, mas para mim o aspecto da fantasia era mais importante. Há sempre uma confusão entre aquilo que o autor quis e o que fez. Posso apenas falar do que pretendi fazer. (GASTÃO, 2011:85). 
Naturalmente, ao que diz respeito a exercícios de estilo deve se determinar o caráter experimental deste movimento. Portanto, a construção de um efeito poético nestes termos se dá através do próprio processo de escrita, da atividade humana que se lança na produção em si; a estruturação musical sobre a qual Franco Alexandre compõe seus poemas destaca inevitavelmente a sonoridade do verso, como, por exemplo, as convulsionadas cadências de "letiersexclu, fantasia política". Aqui, a repetição de fragmentos em diferença nunca conforma um refrão, apresenta, sim, como que uma parede sonora de camadas sobrepostas que, ao fim, dão sentido a um enredo de encontro casual num café em Toulouse. Tal repetição, por conseguinte, acentua o perfil obsessivo desta escrita. A mesma obsessão relativa à imagem poética em torno da qual orbitam as palavras que, entretanto, nunca a têm à mão.

Este apelo à prosódia, tão caro à poesia alexandrina, vem de encontro à perspectiva poética que intenta ensaiar o próprio percurso de escrita enquanto se faz. Neste mesmo sentido que, ao final da leitura, somos avisados de outro "poema escrito / [...] em perfeitas palavras estrangeiras." (ALEXANDRE, 1999:27). Ora, o eu lírico nos noticia que o texto lido não seria mais que um exercício, ensaio, para composição de outro poema, que para o leitor permanece ilegível. E também para o poeta, já que apenas pode falar do que pretendeu escrever. $\mathrm{O}$ estranhamento que poeta e leitor experimentam diante da poesia é este de não reconhecer nela o seu fim, está ele sempre mais além, fora de si mesmo.

Estamos, então, em frente a um paradoxo, fundamental para a compreensão da escrita de Franco Alexandre. Paradigma da modernidade, poíesis e práxis confundem-se na prática de ação humana, afrouxando seus limites, fazendo com que aquela perca seu caráter de desvelamento da verdade e aproxime-se da concepção desta, a qual se fundamenta como gesto de criação no mundo por meio da experiência. Assim, os distintos modos de fazer do homem abandonam em certa medida os domínios do entendimento clássico para consubstanciarem-se sob a alçada do princípio determinante da práxis: a vontade.

Giorgio Agamben, em capítulo propiciamente chamado "poíesis e prâxis", de sua obra $O$ homem sem conteúdo, constrói um quadro histórico assaz esclarecedor a respeito destes modos de fazer a partir do pensamento de alguns filósofos que se detiveram sobre o problema, de Aristóteles à Nietzsche. Observando as variadas metamorfoses que estas concepções realizaram ao longo do tempo, o ensaísta nota a progressiva aproximação de uma em relação à outra. Para os gregos - afirma Agamben -, havia uma clara distinção entre poíesis (pro-dução na presença) e práxis ("fazer, no sentido de agir"), "vontade que se exprime imediatamente na ação" (AGAMBEN, 2012:118). Deste modo, poderíamos dizer que a pro-dução 
tem seu fim fora de si, enquanto a práxis, fechada em seu próprio círculo de ação, deseja a si mesma. As tentativas de perscrutação da obra de arte na modernidade encerram-se em sua interpretação como um modo da práxis que, consecutivamente, é compreendida como vontade (AGAMBEN, 2012:121) havendo, logo, a redução de uma à outra.

Ora, o paradoxo de que falamos diz respeito justamente ao processo de composição poética que, encerrado sobre si mesmo, intenta um fim exterior a si, este ponto não coincidente em que se realiza como vontade absoluta. Falamos, então, de uma práxis superior, ação que se projeta a um saber porvir, a ser continuamente criado, e cuja marca inequívoca é a conciliação entre o homem e a natureza, ser e devir. Em outras palavras, e de acordo com a leitura de Jean-Luc Nancy em seu textoResistência da poesia, compreendemos que o sentido poético está no poema enquanto acesso a um saber outro, ainda desconhecido. Portanto, é como um ato de escrita que abraça o movimento: "o poema é a linguagem em movimento no tempo. Parece-se com um acto, um gesto ou uma série de gestos." (ALEXANDRE apud BARRENTO, 2002:432).

O breve excurso nos retorna ao capricho de Franco Alexandre. Capricho, portanto fantasia, portanto desejo. O desenvolvimento excepcional do poeta neste quesito está em articular a práxis da escritura poética à vontade, impulso criador. Este posicionamento do autor perante o seu objeto é sintomático de um embate operado com/contra a própria linguagem. Assim podemos compreender a asserção que ocupa um lugar central neste estudo: "Há sempre uma confusão entre aquilo que o autor quis e o que fez." Em outras palavras, o que está dito concerne ao fato de que existem dois campos distintos de atuação do poeta, designadamente, um determinado pelo desejo (o que o autor quis) e outro contornado pela realização da obra (o que fez). A poesia, finalmente, não está em nenhum dos dois, estando simultaneamente em ambos; logo, situa-se num lugar tenso, terceiro termo (terceiro excluído?) a que não temos acesso, mas somente nos é dado perscrutá-lo numa busca infinita.

Este passo adiante é dado no reverso do poema, pelo leitor. Ocorre, todavia, a mais arriscada das empreitadas realizadas por esta poesia: a encenação do grande Outro com quem estabelece um ininterrupto diálogo, mas que, se por um lado é aquele em quem deposita a confiança do sentido às palavras proferidas, por outro, con-fundido ao mesmo eu lírico que o interpela torna estéril este movimento de passagem, tendo em vista que somente a diferença pode ser objeto de desejo. Em "letiersexclu, fantasia política" é evidente a suspensão dos discursos advinda de uma indeterminação identitária a qual torna imprecisa a caracterização dos personagens (aqui, bastaria notar as iniciais com que são indicados no texto os personagens, A. e B., assim como uma total indefinição de 
sua sexualidade, além da presença ambígua de um pederasta suíço). Seja como for, a ideia de que a fantasia cumpre um papel fundamental como articuladora da escrita de Franco Alexandre é inescapável, sobretudo quando pensamos sob a perspectiva imagética que este termo encerra - afinal, fantasia é, também, imaginação.

A imagem poética, aqui, pode ser lida como obra da práxis, entretanto, estabelecida como atividade contínua e infinda, já que seu fim está fora de si. Temos, então, que a imagem no poema, enquanto construto de linguagem, é superação da própria linguagem, cujos limites, a priori, a encarceram num precário sistema de significação linguística. A constituição da imagem poética deve, assim, descrever um percurso ascensional cujo resultado mais bem acabado, paradoxalmente, é um processo de naturalização da linguagem, quando, regressada às origens da práxis como atividade humana po excelência, reconhece a vontade como seu princípio movente. Neste lugar, em que a essência da práxis retrocede a uma conotação naturalística do homem, já que a vontade é seu único caráter original, é que pode libertar-se da figura de Deus, pois vontade é também desejo, volição deliberada. Mas, paralelo a isto, é neste mesmo lugar que se dá o movimento de re-ligação em que conjuga o mundo ao divino, e em que se processa a experiência do sagrado.
"Ora eu não era, não fui nunca cristão, por isso sabia / (sem palavras para dizê-lo, aos outros, ou / a mim) que a teologia, incluindo a teologia suíça, / é uma coisa carnal, antes de pensada / sentida nas vísceras, na agonia dos corpos" (ALEXANDRE, 1999:13). A elaboração da imagem (poética) prescinde de palavras, melhor dizendo, por meio de seu uso, superam-no. Porque é uma "coisa carnal", esta teologia é sentida "na agonia dos corpos", "por isso a teologia é teológico-política." (ALEXANDRE, 1999:13), assim completa o eu lírico. O caráter visceral apontado no fragmento em destaque parece-me sintomático da perspectivação naturalística que encontra a vontade no seio da práxis, sendo ele mesmo o protagonista desta motivação que busca um sentido (outro) por meio da relação teo-lógica. Assim, temos a leitura incontornável de Pedro Eiras deste poema, muito acertadamente tratando deste tópico: "Teologia, por isso erotismo, por isso política, por isso teologia: numa deslocação de sentidos coordenados, testando a hipótese de uma unidade adâmica sob a babel dos conceitos." (EIRAS, 2009, p. 25). Sob a babel dos conceitos ("letiersexclu, fantasia política" é um texto visitado também pela língua francesa, como vemos já no título, assim como apresenta uma série de referências a espaços culturais estrangeiros) subsiste uma unidade. Ora, é a esta unidade que se projeta o poeta para a conformação da imagem, em que a palavra retoma seu estatuto de correspondência com o mundo (seu estado natural) e com ele é una, não mais instaurada 
sob um regime de representação, mas apresentando-o em seus ininterruptos movimentos de metamorfose.

Assim, somos chegados ao ponto em que a práxis, sendo aquilo que nos move do que somos ao que podemos ser, é também o que move (transforma) o mundo. A faceta política manifesta neste quadro cumpre fundar um lugar comum. No âmbito do poema este espaço só poderia ser o da leitura posto que este engendra, não só um intercâmbio, uma relação de partilha, mas também um movimento de pro-dução Deste modo, observamos que, no seio da ação humana, é visada a continuidade, o não estranhamento, de modo que práxis cria uma relação de paridade com os homens, que se reconhecem no princípio original da "atividade livre e consciente" como vontade (AGAMBEN, 2012:134-135).

A inscrição do outro no espaço do texto talvez seja das marcas mais significativas da lírica alexandrina, principalmente se a compreendermos no que diz respeito à busca do sentido poético. Este movimento de alteridade intenta precisamente a revelação do ser ao homem, muito emboraa desestruturação de uma imagem do mundo tem como consequência o esfacelamento da possibilidade de construção da imagem poética. Neste sentido, a leitura da obra de Franco Alexandre a partir de sua radical descontinuidade, que se experimenta em variadas metamorfoses, texto a texto, assim como de alguns procedimentos estilísticos que apostam na quebra da construção discursiva, pode se fundamentar em algo como uma poética de fragmentos, posto que, diante da fratura operada pela linguagem poética sobre o real, somente somos capazes de captar o objeto estético sob uma lente multifocal.

A estruturação partida de Quatro caprichos é ainda mais acentuada na segunda estância do livro denominada "corto viaggiosentimentale, capriccio italiano". Aqui, somos apresentados a uma série de 39 segmentos poéticos que compõem um descontínuo enredo, ou, segundo as palavras do autor: "Trata-se de um poema narrativo com várias narrações simultâneas." (GASTÃO, 2011:86). Assim, se por um lado tal aspecto formal pode ser sintomático de uma concepção da linguagem (e do mundo) sob a égide da análise, por outro, é por meio deste mesmo procedimento que se lança à comunhão com o outro, neste caso, tomada pela multiplicidade de vozes que se cruzam no texto. Natural que, no poema de Franco Alexandre, este processo se manifeste a partir de uma dinâmica de encontros e desencontros, de modo que acaba por se formar um complexo enunciativo de dicções que se contrapõem.

Enfim, o leitor que acompanha estes deslocamentos discursivos experimenta aquela mesma tensão de uma poética nômada a que Joaquim Manuel Magalhães já observou em ensaio sobre o poeta de Sem palavras nem coisas 
(MAGALHÃES, 1981:247-248). É este o mesmo estranhamento que pode nos provocar a fruição estética destes versos que, não por acaso, lançam-se à incursão de línguas estrangeiras. E, assim como Pedro Eiras, também "Prefiro pensar o lugar da língua do outro a partir do desejo, que o torna estranho-por-isso-fascinante.", afinal, "Só a dissonância pode ser desejada." (EIRAS, 2009:26). Ora, a linguagem poética de Franco Alexandre também não nos causa este mesmo estranhamento? Não seria ela, assim, uma abertura a um lugar outro do dizer, ao modo de uma língua estrangeira emergindo de dentro da própria língua mãe? "não havendo limites ao que podemos / imaginar, as bocas facilmente se tocam / e duas diferentes línguas se / respondem, condolceviolenza. / Que mais desejarias ter / numa outra vida: o meu talento, / o le mie gambe?" (ALEXANDRE, 1999:31).

Neste poema, a relação entre potência e imaginação, suscitada pelo enjambement que liga os primeiros versos, encontra-se no ilimitado figurado pela intensa carga erótica de um encontro de bocas que se tocam. À medida que se desencadeia este movimento, podemos associá-lo ao gesto de leitura, quando "duas diferentes línguas se / respondem, condolceviolenza." A ideia de elaboração de um lugar comum a partir da interlocução poética se faz por meio do signo da responsabilidade, que ambos assumem relativamente à construção de sentido, sem que deste encontro se elimine o

choque proveniente das dissonâncias entre si. Por isto assinala a dolceviolenza da experiência poética, e é esta mesma doce violência que, na obra alexandrina, é figurada como quebra, fratura do mundo, repercutida na linguagem.

Quando perguntado por Ana Marques Gastão acerca do que seja "amar o vazio" de que fala, Franco Alexandre propõe, em breves palavras, uma severa reflexão sobre a natureza de Deus, o que, consecutivamente, pode nos levar a uma problematização da experiência do sagrado em sua poesia. Destaquemos este fragmento para que, então, possamos desdobrar esta discussão em tópicos afins. Sobre o trecho inquirido pela entrevistadora, o poeta afirma:

Essa dir-se-ia a frase mais explicitamente metafísica do livro. Não há linguagem para falar dessas coisas. As pessoas falam de Deus e a palavra soa-nos estranha, associada que está a imagens absurdas. Parece um termo genérico. Falta um nome próprio. Vazio é uma palavra melhor que Deus. Aquele que ainda não há, que nunca chega a ser. Se eu soubesse falar dessas coisas escreveria um livro de filosofia. (GASTÃO, 2011:88).

Este comentário, parece-me, apresenta uma interessante perspectiva sobre o fazer poético. Observamos que o poeta encerra uma distinção entre filosofia e poesia na medida em que esta, inexoravelmente, trataria do que não conseguimos dizer, ou melhor colocando, da busca de um sentido que se 
elude insistentemente por trás dos signos, prática que se impõe como luta com a linguagem, já que ela, nestas circunstâncias, estaria sempre em falta. Consequentemente, se Franco Alexandre "soubesse falar dessas coisas escreveria um livro de filosofia"; talvez porque, no âmbito filosófico, a abordagem mais estritamente crítica dependa de método rigor científico, precisão em muito diferente da concernente à poesia. Quanto a esta, não só enfrenta o desconhecido, o vazio, "aquele que ainda não há, que nunca chega a ser", mas do seio desta mesma ausência o obriga a falar para fazer emergir um saber por vir.

A potência de criação move este saber por vir, projetado sobre o corpo do outro. O tu na obra alexandrina é aquele que responde e faz responder a um eu que anseia pelo encontro. Estamos diante de uma relação amorosa inscrita na interlocução obra/leitor, poema enquanto gesto de amor procedimento estético que muitas vezes irá recobrar algumas manifestações da tradição lírica sentimental: "Desejo meu, em tua sede habito; / meu mestre, escravo, amante, pois servimos / no mesmo chão o mesmo antigo lume." (ALEXANDRE, 1999:83). Os versos que encerram o livro não só retomam a diç̧ão medieval de uma vassalagem em que amador e amante são mutuamente subordinados, como, operando um movimento que transita da diferença (outro) à semelhança (mesmo), situa tanto eu lírico quanto este tu (que pode se assimilar à imagem do leitor inscrita no poema) em posição de súditos do "mesmo antigo lume". A referência pode ser atribuída a própria poesia, posto que obra e leitor ocupam este lugar tenso relativamente à tradição, espaço de permanência e transformação movida pela leitura.

A alteridade que se processa a partir deste movimento busca a continuidade, instante em que se daria a conciliação entre o terreno e o divino, matéria e espírito. A suspensão temporal suscitada pela leitura do poema seria transcendência do homem na projeção de sua própria imagem, momento em que o homem é a sua imagem, portanto, encontro entre vontade e fantasia. Deste quadro, em que o sujeito se manifesta como potência absoluta, é-nos revelado o sagrado enquanto experiência carnal:

venho dormir junto de ti

e o meu corpo é uma coisa diferente

do que se vê ou toca ou sente;

é, fora de mim, essa coluna de ar onde respiro, olhos que beijam o teu corpo exacto,

as muitas mãos que dobram o teu rosto.

Um deus que dorme, um deus que dança, e mais que um mero deus, o breve amor do tempo.

(ALEXANDRE, 1999:42). 
O poema, que sugere em seus primeiros versos tanto um possível encontro sexual como uma abertura ao espaço onírico, salienta, consequentemente, a intersecção destes dois planos: aqui, fantasia erótica e imaginação criativa confundem-se sob a presença de um outro que perscruta o olhar do observador (leitor) de um corpo esquivo. Poderíamos chamar um corpo de sentidos, já que está a meio caminho entre a significação e o universo sensível, compondo um só organismo vivo que, curiosamente, apenas ganha vida por meio da alteridade, porque este corpo "é, fora de mim, essa coluna de ar onde respiro”. O sentido poético está alhures, construindo-se a partir do choque com uma língua diferente, a do leitor, que, neste caso, sofre mesmo um processo de inversão, muito característico da poesia alexandrina, quando deixa a condição de sujeito para assumir o papel de objeto. $\mathrm{O}$ leitor é, também, obra a ser lida pelo poema que descobre o próprio corpo no outro. A dobra, que indicia o ato de virar a página de um livro assim como operação multiplicativa, é relacionada ao rosto deste tu que vislumbra o texto e que, finalmente, nele se lia.

Quanto ao deus que dança (trecho que ecoa Zaratustra), supomos um gesto ritual, momento em que leitor e obra comungam da expressão poética como devir do mundo e, simultaneamente, reconhecem neste projeto seu próprio ser. $\mathrm{Na}$ consumação da imagem poética por meio da interlocução, inaugura-se outro tempo, fora do tempo, pois o sujeito se consubstancia ao próprio movimento enquanto manifestação de vontade absoluta. Neste sentido, ser e devir se confundem e o poema torna-se, não apenas consciência histórica por excelência, mas desejo de ultrapassá-la, transcendê-la. Há, por conseguinte, uma intrínseca afirmação política do homem na aprovação de sua independência, afinal, é ele o responsável por balizar os movimentos da história. Assim que, como modo de agir, encontramos, no seio da prática poética, igualmente a forma plena de transformação do mundo e sua construção como lugar comum:

Talvez consciência histórica e necessidade de transcender a história não sejam mais do que os nomes que agora damos a este antigo e perpétuo desgarramento do ser, sempre separado de si, sempre em busca de si. O homem quer identificar-se com suas criações, reunir-se consigo mesmo e com seus semelhantes: ser o mundo sem cessar de ser ele mesmo. Nossa poesia é consciência da separação e tentativa de reunir o que foi separado. (PAZ, 2009:122-123)

Assim, podemos falar, com Franco Alexandre, sobre amar o vazio. Também nós leitores experimentamos, ao enveredar pelos versos do poeta, este vazio, silêncio primordial que as construções imagéticas desta poesia fazem ecoar. É pela musicalidade presente em seus poemas que podemos regressar a 
natureza mais íntima da linguagem, quando a ouvimos soar o rumor em que nada se diz, para que, em seguida, dela possa nascer o homem em plena volição deliberante, projetando-se para o outro: "Penso numa música nunca ouvida, música para os olhos, um música nunca vista." (PAZ, 2009: 110).

Esta mesma perspectiva destacada por Octavio Paz, que tangencia o que procuramos conceber como uma poética de fragmentos, dá-nos a entender com maior clareza os procedimentos estéticos do poeta português, pois, na medida em que se fala de uma "consciência da separação" e a consequente re-união de si, nos chama a atenção o processo de recolha vigente nestes versos. $\mathrm{E}$ justamente tratamos desta característica, não no que diz respeito a um aspecto organizaciona de seus livros (que, como já aqui abordamos, determina cada uma de suas obras num universo profundamente particular) mas no que tange a um recurso estilístico que atravessa toda a construção discursiva que fundamenta cada um de seus títulos. Em Duende - assim como em Uma fábula e Aracne, livros-poemas que conformam uma espécie de tríade no viés das metamorfoses ovidianas -, a ideia de erigir um construto poético polifônico é sintomática desta fissão experimentada pelo eu lírico que se dilui em diversas vozes. A dinâmica que aqui se trabalha é precisamente a da encenação de um jogo lírico-amoroso, em meio a encontros e desencontros os quais se processam no espaço do poema como relação comunicativa entre obra/leitor.

Pensando na polifonia que percorre toda a obra referida, Luis Maffei, em texto denominado "Situações do amor noDuende de António Franco Alexandre”assinala o diálogo intertextual que se fundamenta como recuperação, em diferença, da tradição. $\mathrm{O}$ espaço entre em que se situa este eu lírico é demarcado, sobretudo, por uma multiplicidade de vozes que o atravessa e, neste mesmo movimento, é reabilitada; a relação amorosa que se insinua no texto é figurada tanto num concílio entre obra e leitor como num diálogo poético: "Portanto, ao amor que tem, porventura, lugar a partir do vitalismo intrínseco disso que é um sentimento, une-se o amor da tradição: pela tradição" (MAFFEI, 2005:323). Acreditamos que o principal contributo deste ensaiode Luis Maffei consiste na perscrutação das mais variadas formas de manifestação lírico-amorosa, observando como esta composição de fragmentos não tem como finalidade um objeto estético totalizante, de cunho inocentemente redentor. Pelo contrário, a reunião de vozes dissonantes no espaco do poema repercute a mesma complexidade da vida, tantas vezes contraditória, e pouco ou nada nos é dado que nos responda a um questionamento existencial, tão presente nos versos de Franco Alexandre. 
"Por sorte andas bem longe, lá por fora, / já me esqueci de ti completamente. / É mais fácil assim, saber-te ausente, / corre mais fina a vida junto à morte." (ALEXANDRE, 2002:14). A figuração da morte como horizonte da existência é trabalhada insistentemente nesta obra. Observada num ciclo de metamorfoses, ela é ingrediente imprescindível para a transformação; na medida em que a compreendemos como movimento de passagem, é incorporação no circuito temporal em que ser e devir se reconciliam. Neste âmbito, a consciência da finitude corresponde a uma aprovação da vida sendo a obra humana testemunho maior da vontade que é criação diante do vazio a que se lança o homem. Portanto falamos de um recobrar do desejo que, como uma prática de re-ligação com o sagrado, intenta a afirmação de um projeto de humanidade. Assim mesmo poderíamos ler os primeiros versos do livro-poema: "Fosses tu deus, seria eu santo / alimentado a areia e gafanhotos, / sem cessar meditando o único nome / que o horizonte deserto não contém." (ALEXANDRE, 2002:9). O estado meditativo do eu lírico é, aqui, índice de uma separação; estamos diante de um sujeito em trânsito, perspectiva corroborada pela imagem do deserto, espaço de deslocamento. Entretanto, o que podemos ler como mediação acena para uma vertiginosa autoconsciência a qual se esbate com os limites da própria existência. A possível alteridade como movimento transcendente se defronta com uma morte que apenas indica um termo final, a precariedade do corpo (para observarmos este aspecto, bastaria notar a presença de vocábulos como esquecimento, vazio, ausência, que reiteram a interrupção de qualquer transcendência nestes poemas). O contraponto deste encadeamento discursivo se processa como desvio, fratura da linguagem, transgressão. Paradoxalmente, tal ruptura, à maneira de uma figuração do erotismo, corresponde a uma forma de re-ligação, de alteridade no corpo de outrem: "o sexo feito em Duende tampouco será escusado e, muito menos, iníquo, mesmo porque a religião aqui insinuada é outra" (MAFFEI, 2005:324). Neste mesmo sentido, Maffei assinala que o objeto amado é também divinizável e a transformação desejada se opera como encontro erótico, quando amador e objeto amado dissolvem-se um no outro, ao modo camoniano do "Transforma-se o amador na cousa amada". A este respeito, o ensaísta afirma que:

[...] crê o sujeito poético amoroso numa certa divinização da figura amada, pois é ela quem pode pôr em estado de realidade o erotismo; e o erotismo, sem dúvida, e o amor, revelam-se, um tanto camonianamente, como assunção de que existe uma falha original no humano que tão-somente o amor pode cobrir. (MAFFEI, 2005:326).

Ora, a plena condição humana é a condição amorosa. Por isto, também, na poesia de Franco Alexandre, a humanidade 
é vista como projeto. Prosseguindo este argumento, notamos que o sujeito em estado amoroso é aquele que se assume em plena vontade e que, portanto, é capaz de enfrentar a própria morte. Assim, o suicídio, como o único gesto efetivo do homem em seu domínio, faz-se marca inequívoca do amador. Há neste ato as marcas de uma experiência limite a qual, simbolicamente, é recuperada como rito sacrificial: "como o místico leio nas entranhas / da ausência a tua sombra desenhada." (ALEXANDRE, 2002:9). O fragmento, que em muito lembra a expressão do horror vivenciada perante a visão da pletora dos órgãos de que fala Georges Bataille em seu $O$ erotismo (BATAILLE, 2004:150) , sintomaticamente aponta para uma prática de leitura. A partir de uma experiência intimamente carnal, pode se ter acesso a uma união direta com o divino, e, aqui, poderíamos retomar a ideia de amar o vazio de que fala Franco Alexandre. A ausência inscrita no poema, portanto, situa-se a meio do caminho de um saber por vir e que, continuamente, luta-se por construir. Neste sentido, o poeta é o agente criador de um saber que lhe é exterior e que dele sempre se esquiva - por isto mesmo sua relação com a linguagem se dá como desvio.

Há notícias de algum mistério nestes mesmos versos. $\mathrm{O}$ gesto de leitura é realizado por um místico, o que nos leva a associá-lo a uma operação cujos atributos são da ordem de um movimento de consagração. Por outro lado, seu objeto é

a "sombra desenhada" de um tu "nas entranhas da ausência". A imagem da sombra ocupa um lugar de ambivalência no poema, posto que, enquanto se associa à sugestão do rosto de outrem sobre o livro aberto, também é marca característica da presença da morte, aqui profundamente assimilada ao esquecimento, à ausência de interlocução: "Porque sei que me esqueces é que lembro / cada instante o que perco e não vem mais." (ALEXANDRE, 2002:9).

Talvez das mais complexas problemáticas da poesia alexandrina, isto a que Rosa Maria Martelo reconheceu como os efeitos de indecidibilidade de sua linguagem é constantemente notado em marcas textuais que indiciam uma profunda incerteza quanto à estabilização de algum sentido discursivo em seus poemas (MARTELO, 2010:202). Como consequência de tais procedimentos, o problema da interlocução pode ser observado como encenação expressa no próprio espaço literário:

A discursividade do texto poético evidencia uma percepção de encontros e desencontros perante entidades derramadas na sua definição, situadas entre um eu e um tu, com fronteiras variadas, por vezes desencontradas. (SILVA, 2007:98).

Este desencontro, salientado por João Amadeu Carvalho da Silva em ensaio seminal sobre Duende, associa-se, contrariamente à con-fusão dos corpos em estado amoroso, à 
margem de perda da distinção identitária entre os sujeitos amantes, o que acaba por anular o desejo: "É precisamente a rasura da identidade que impossibilita a aproximação; num espaço amorfo e sem rostos, indistinguem-se os corpos e torna-se impossível o amor." (SILVA, 2007:99).

Tal desencontro também pode ser notado na estruturação da obra em desacertados 52 sonetos. Curiosamente, é ensaiado um suposto fechamento no poema 50: "Pousado o coração dentro do peito, / feito artista da cor, puro fantasma, / na ardósia a giz desenharei um nome / como quem traça um círculo perfeito." (ALEXANDRE, 2002:58). A expressão, que, aliás, demarca pelo excesso uma imperfeição (lemos, aqui, o pleonasmo de "círculo perfeito"), não nos oferece a garantia de uma experiência de totalidade, pelo contrário, a representação assinalada pelo desenhar do eu lírico corresponde a um aspecto igualmente corrosivo da criação que a palavra traçar põe em discussão. Elabora-se, então, a ideia de perda, tão cara a esta poesia, de forma que a construção de sentido pela interlocução se torna duplamente problemática, posto que tanto o outro como as palavras que ligam o eu a ao outro são fantasmas neste diálogo.

Frente a esta perspectiva de nulidade relativamente à forca transformadora da palavra poética, o poeta encerra em sua escritura um gesto de fé. Ao inscrever no espaço do texto um tu a que continuamente se projeta, mantém intrínseco laço com o incriado, é uma aposta na propriedade fecundante da palavra proferida, já que "[...] pensar em ti é ter seguro / outro universo inteiro onde não estou." (ALEXANDRE, 2002:51). É notável como não há nada de seguro neste movimento, pois este pensar de que fala o eu lírico é já marca de uma fissura, deslocamento para um espaço de ausência, afinal, neste "outro universo" ele não está. Há um risco neste trajeto que insistentemente é abordado na obra de Franco Alexandre e, todavia, é por meio deste deslocamento que se fundamenta um dos aspectos centrais de sua poética: gesto que coloca as demais subjetividades líricas perante a incerteza do encontro com o outro.

Como dirá Octavio Paz, a poesia moderna encerra uma interrogação; uma pergunta acerca do sentido poético que nada mais é do que uma inquirição sobre o sentido histórico, cuja figuração corresponde a uma fraturada imagem do mundo. No caso da poética alexandrina, o apelo incerto pela presença deste outro se torna desejo de constituição de um lugar comum, busca de um sentido que se conforma por meio do encontro entre corpos. Dirá Maffei que "É no corpo [...] que pode morar uma verdade amorosa" (MAFFEI, 2005:325). A partir desta afirmação, associamos o movimento erótico a um efeito de desvelamento do real que, na poesia de Franco Alexandre, não deixa nunca de referenciá-lo como uma falta. A tentativa de composição de uma imagem

EM TESE

BELO HORIZONTE

v. 19

N. 2

AG0.-OUT. 2013

SOUSA. 0 lugar comum da poesia de António Franco Alexandre [...]

P. $95-110$ 
poética é necessariamente falha porque repercute uma desestruturada imagem do mundo. Deste modo, o entendimento de uma poética de fragmentos é-nos mais evidente a partir do reconhecimento do caráter alegórico constitutivo do poema. O distanciamento do outro é, sintomaticamente, o índice de uma busca de sentido, que está sempre alhures. Ora, de acordo com a abordagem que viemos tratando até então, destacamos este outro como um leitor por vir. O poema cria o seu leitor num gesto prospectivo.

O poema também não seria este espaço oco, a se criar continuamente a partir da leitura? A comunicação possível se dá como troca entre dois corpos, experiência sensível que prescinde da significação. Interroga-se até mesmo o eu lírico se existirá "outro mundo além da pele." (ALEXANDRE, 2002:12). Este saber do corpo, sanguíneo e visceral, é o que permite, ao menos provisoriamente, suprir este vazio, enquanto o afirma. A consciência da precariedade deste encontro é assimilada pela única certeza que habita os versos de Franco Alexandre: a morte. Assim, este mesmo vazio se torna manifestação do apagamento da alteridade, esquecimento: "Entre os meus dedos fica o lugar oco / onde tão certo deixo esse postal / ilustrado do teu esquecimento." (ALEXANDRE, 2002:14). Portanto entre encontros e desencontros, como diz João Amadeu Oliveira Carvalho da Silva, a concepção de um corpo de sentidos parece pertinente

para um entendimento da poética alexandrina, posto que assinala, na corporeidade que é vigente em seus versos, simultaneamente, tanto um apelo aos sentidos (signos sensíveis) quanto a finitude da matéria. A linguagem deste poeta caminha entre estas duas possibilidades: uma morte transitiva no corpo erótico do outro, ou uma morte intransitiva, marca da perda a que todos estamos já fadados.

Fica dentro de mim como se fosse eterno o movimento do teu corpo, e na carne rasgada ainda pudesse

a noite escura iluminar-te o rosto.

No teu suor é que adivinho o rastro

das palavras de amor que não disseste, e no teu dorso escuro escrevo o verso em pura solidão acontecido.

Transformo-me nas coisas que tocaste crescem-me seios com que te alimente o coração demente e mal fingido; depois serei a forma que deixaste gravada a lume com sabor a cio na carícia de um gesto fugidio.

\section{(ALEXANDRE, 2002:11).}

No soneto 3 de Duende, constatamos esta voz vacilante entre a morte e a eternidade. A suspensão discursiva operada 
pelo enjambement - recurso, aliás, usado com perícia pelo poeta - dos primeiros versos coloca em xeque um projeto de alteridade. O como se, sendo abertura ao plano ficcional é, aqui, intersecção entre dois mundos, reconciliação entre carne e espírito por meio do explícito movimento erótico figurado. É, por conseguinte, também abertura à eternidade, suspensão temporal experimentada na fusão entre corpos. Por outro lado, há uma veemente desestruturação destes mesmos esquemas no uso das formas verbais no pretérito imperfeito do subjuntivo, que mais não fazem que assinalar a insistente condicional que ameaça toda construção discursiva. Assim, o desejo de ser penetrado do eu lírico é transgressão que apenas indicia um distante vislumbre do infinito, pois o movimento do corpo do outro é "como se fosse / eterno", portanto, finito, mortal.

O encontro erótico é incessantemente reatualizado como potência por se realizar. Natural que o desejo de eternidade só possa ser anseio do ser mortal, logo, ressaltamos o pape imprescindível que a morte assume neste que é dos tópicos centrais da lírica alexandrina: a metamorfose. A transformação, todavia, opera-se fragmentariamente, a perseguir rastros do outro. "Transformo-me nas coisas que tocaste, crescem-me seios com que te alimente / o coração demente e mal fingido;" O profundo teor erótico como que demarca uma incestuosa maternidade por meio da figuração dos seios, aqui, um sexual deleite no regresso a um saber original. Fonte de vida e seguro recanto, estes seios alimentam, são acesso a um conhecimento interdito indicado na violência da "carne rasgada". Esta mesma violência associada ao erotismo pode muito bem relacionar-se com o gesto de escritura poética, na medida em este também assinala uma desmedida, extrapola os limites da significação. Tais efeitos são considerados nos usos de uma atenção prosódica a conformar um mesmo "gesto fugidio". Porventura uma aproximação fônica entre fingido e fugidio dá-nos exemplo como que de uma arte poética alexandrina. Recuperando uma dicção pessoana (já muito presente em sua obra e com especial importância em Duende), o fingimento de Franco Alexandre salienta o caráter esquivo relativamente ao sentido poético buscado e é também isto cuja forma é moldada pelo outro (o leitor): "depois serei a forma que deixaste". A musicalidade dos versos de Franco Alexandre cumpre uma rarefação dos significados, de forma que o sentido poético aludido apenas é conseguido como relação corpórea. As palavras de amor não ditas (ou melhor, interditas) são, porventura, sugeridas na inscrição do/no corpo do outro que, pela "musicalidade do verso, um ritmo interno, um combinar difuso de sons" (SILVA, 2007:101), consagra a constituição de um sentido outro, em que imagem e som confundem-se na intenção de aceder a um novo espaço criado, movimento unicamente engendrado pela interlocução. 


\section{REFERÊNCIAS}

AGAMBEN, Giorgio. Poíesis e práxis. In. O homem sem

conteúdo. Tradução, notas e posfácio de Cláudio Oliveira. Belo Horizonte: Autêntica Editora, 2012.

ALEXANDRE, António Franco. Duende. Lisboa: Assírio \& Alvim, 2002

ALEXANDRE, António Franco. Quatro caprichos. Lisboa: Assírio \& Alvim, 1999

BARRENTO, João. O poema 16 [de Dos Jogos de Inverno]. In Século de Ouro: Antologia Crítica da Poesia Portuguesa do Século XX / SERRA, Pedro e SILVESTRE, Osvaldo Manuel (Org.). Lisboa: AngelusNovus\& Cotovia, 2002, p. 431-436.

BATAILLE, Georges. 0 erotismo. Tradução de Cláudia Fares. São Paulo: Arx, 2004

EIRAS, Pedro. A língua excluída do poema - Sobre "letiersexclu, fantasia política" de António Franco Alexandre. In. Portuguese Cultural Studies, 2, Winter 2000, p. 23-29.

GASTÃO, Ana Marques. António Franco Alexandre dos poetas. Porto: Edições Afrontamento, 2011

MAFFEI, Luis. Situações do amor no Duende de António Franco Alexandre. Revista Camoniana n. 18. Bauru: Editora da USC 2005. pp. 323-337.
MAGALHÃES, Joaquim Manuel. António Franco Alexandre. In. Os dois crepúsculos: Sobre poesia portuguesa actual e outras crônicas. Lisboa: A regra do jogo, 1981.

MARTELO, Rosa Maria. O "especialista em sublimação" e os usos da linguagem. In. A forma informe. Lisboa: Assírio \& Alvim, 2010.

NANCY, Jean-Luc. Fazer, a poesia. In. Resistência da poesia Tradução de Bruno Duarte. Lisboa: Vendaval, 2005.

PAZ, Octavio. Signos em rotação. Tradução de Sebastião

Uchoa Leite. Organização e revisão de Celso Lafer e Haroldo de Campos. São Paulo: Perspectiva, 2009.

SILVA, João Amadeu Oliveira Carvalho da. A poesia de António Franco Alexandre ou "o signo de uma ausência no fundo das imagens". In. Revista Portuguesa de Humanidades, 11/12

Tomo 2, 2007, p. 97-126. 